\title{
The Research of Asset Price Bubble at Borsa Istanbul and Financial Crisis Relationship ${ }^{1}$ Borsa İstanbul'da Varlık Fiyatı Kabarcığı Araştırması ve Finansal Kriz İlişkisi
}

\section{PhD. Müge Sağlam Bezgin ${ }^{2}$ - Prof. Dr. Mehmet Başar}

Başvuru Tarihi: 13.12.2019

Kabul Tarihi: 17.06 .2020

Makale Türü: Araştırma Makalesi

\begin{abstract}
In this study, the asset price bubble in Borsa Istanbul was examined through the right-tailed unit root test. The index where the bubble research was conducted is Borsa Istanbul 100 return index. The study period was determined as 1997-2018 period considering the increase in the index transaction volume. Macroeconomic variables identified as indicators of financial crises were; gross domestic product, foreign trade deficit, total foreign debt, real exchange rate, budget deficit, credit / gross domestic product, interest rate, domestic credit volume, money supply and inflation. The relationship between these variables and bubbles was examined with asymmetric causality test.
\end{abstract}

Keywords: Asset Price Bubble, Financial Crisis, Right Tailed Unit Root Test, Asymmetric Causality, Time Series Analysis

Öz

Bu çalışmada Borsa İstanbul'da varlık fiyatı balonu araştırması sağ kuyruk birim kök testleri vasıtasıyla incelenmiştir. Balon araştırmasının yapıldığı endeks Borsa İstanbul 100 getiri endeksidir. Çalışma dönemi endeks işlem hacmindeki artış göz önüne alınarak 1997-2018 dönemi olarak belirlenmiştir. Finansal krizlerin göstergesi olarak belirlenen makroekonomik değişkenler; gayrisafi yurtiçi hasıla, dış ticaret açığı, toplam dış borç, reel döviz kuru, bütçe açığı, kredi/gayri safi yurtiçi hasıla, faiz oranı, yurtiçi kredi hacmi, para arzı ve enflasyondur. Bu değişkenler ve balonlar arasındaki ilişki asimetrik nedensellik testiyle incelenmiştir.

Anahtar Kelimeler: Varlık Fiyatı Balonu, Finansal Kriz, Să̆ Kuyruk Birim Kök Testi, Asimetrik Nedensellik, Zaman Serisi Analizi

\footnotetext{
1 This study is derived from the doctoral thesis conducted under the supervision of Prof. Dr. Mehmet Başar.

${ }^{2}$ Karamanoglu Mehmetbey University, Faculty of Economics and Administrative Sciences, Department of Business Administration, mugesaglam@kmu.edu.tr, ORCID: 0000-0001-8674-2707

3 Anadolu University, Faculty of Economics and Administrative Sciences, Department of Business Administration, mbaser@anadolu.edu.tr, ORCID: 0000-0003-4989-0502
} 


\section{Introduction}

The bubbles, defined as the deviation of asset prices from their core values, are expressed as difficult movements to identify and define. In particular, the detection of a bubble in emerging markets such as Turkey is extremely important for both domestic and foreign investors as well as policymakers. However, considering the academic environment, it is seen that bubble tests are limited and the interpretation of index fluctuations for the Turkish Market is attempted to be expressed by ARCH group models. In other words, the existing examinations regarding whether the fluctuations are a market bubble are seen limited. In recent econometric applications, it has been understood that asset price bubbles can be detected retrospectively. In addition, it is asserted that structural financial crises can be predicted with the bubbles by evaluating the economic policies implemented in bubble periods based on the conditions. Kindleberger and Aliber (2011a), in their study of financial panics, argue that the decrease in interest rates increases consumption and borrowing instinct and this creates a bubble in asset prices. Kindleberger and Aliber also state that the burst of the bubble in asset prices causes a financial crisis and they explain these claims with Minsky's Financial Instability Hypothesis.

In this context, the main problems of this study can be listed as the necessity of testing the following assumptions: bubbles cannot effectively be detected econometrically; bubble research is limited to developed markets; the assertion that bubbles are associated with economic crises and assumption that bubbles appeared a period before the financial crises.

The main purposes of the study are (a) to test the presence of bubbles practically, (b) an examination of the relationship of bubbles crises observed in Turkey and (c) to create an opportunity to look at the economic crises from a different perspective by testing Kindleberger's bubble theory. Another aim of the study is that the studies on this subject are limited to the real estate market. In addition, this study will contribute to the bubble research in the developing markets as the bubble studies are mostly on developed markets. In addition, it is thought that the method applied in this study will contribute to the literature of the researchers who make researches and detection of bubbles. By examining the bubbles and financial crises, in other words by investigating the causality between them, it is aimed to shed light on the question of whether bubbles can be the leading indicator of financial crises.

\section{Theory: Financial Bubbles and Financial Crises}

The term bubble is used for the sudden increase in the price of an asset and in cases where this increase is sensitive to a collapse (Barlevy, 2007, p. 45). Kindleberger (1978a) expresses the bubble as an upward price movement that will explode later. Watanabe et al. (2007) define the concept simply as the deviation of the price of an asset from its basic value. The bubble generally does not involve the purpose of obtaining a return on investment from an asset, but the purpose of selling that asset to others at a higher price. From this point, it is assumed that speculative attacks are the basis of the bubbles. According to Stiglitz (1990, pp. 13-18), although the indicators do not confirm, if the investors believe that the selling price will be higher tomorrow, it means that the bubble has occurred. 
What is important here is that not all fluctuations in the market are characterized as bubbles. On this issue, Komaromi (2004) emphasized that the following features should be present in order to distinguish a bubble from other fluctuations in the stock market (Komoromi, 2004, pp. 8-13). Accordingly, factors such as a permanent and strong increase in asset prices; the condition that an increase in prices strengthens investors' optimistic expectations for the coming period; a significant increase in total trading volume in the stock market and causation of the macroeconomic effects cause a market movement to be evaluated as a bubble.

According to Blanchard and Watson (1982), bubbles are divided into two. The fact that asset prices fall below the base value also implies a negative bubble, but in practice, the bubble is a positive bubble that is above the core value of asset prices (Blanchard and Watson, 1982, p. 8).

In the theory described by Blanchard and Watson (1982), market actors are aware of the existence of a financial bubble, but with the motive of making a profit, they knowingly invest in a bubble-formed asset. The aim here is to get capital gain by selling the asset at a higher price later. It is important that the speculator, aware of the bubble, knows when the bubble will explode. As long as investors who love risk and find it rational to invest in a bubbling asset, the bubble will grow and survive as long as they trade in the markets. If there is an infinite amount of potential investors to enter the market, the bubble will last forever under the optimistic expectations of those who have already purchased the assets (Blanchard and Watson, 1982, p. 8 ). The burst of the bubble occurs as a result of financial shocks and the severe deterioration in expectations resulting from these shocks, with the reaction of potential investors not to enter the market. After the burst, according to the severity of the burst, a crisis occurs in the market.

Kindleberger and Aliber (2011a) examine a bubble in three stages: Accordingly, the first stage is the stage in which the investor borrowing easily and cheaply in a good economic environment turns to the purchase of assets. Brunnermeir and Oehmke (2012) describe this phase as an increase in profits after financial or technological innovation. This stage is seen as the initial stage of the bubble. At the beginning of the universe, asset prices are increasing at a low rate. After this phase, the masses expect rises in price and increase their asset purchases. Along with purchases, the upward trend in the price of the asset accelerates. At this point, investors may be aware that there may be a bubble, or at least they may suspect the presence of a bubble, but they continue to make purchases because they are confident that they can sell their assets to a larger 'fool' ${ }^{\prime}$ in the future (Brunnermeir and Oehmke, 2012, p. 12). The investor, who is convinced that he will sell the asset at a higher price at a later date, continues his purchases and this phase is described as "mania" phase by Kindleberger and Aliber. In the literature, this phase is generally associated with high throughput. The second phase, which Kindleberger and Aliber treat as critical, is the bursting point of the bubble. In this phase, one or more market participants go into sales and sales accelerate as prices go into a downward trend. The collapse comes with the acceleration of sales. Kindleberger and Aliber (2015b) treat the burst and collapse as a series of steps leading to the financial crisis. Thus, the association of the collapse phase with crises has led to the need to test the causality test as well as the detection of bubbles. 
In economic science, the crisis is generally defined as a sudden unfavourable development. In the economic literature, there are various definitions according to different economic approaches. The main definitions of crisis are as follows;

$\checkmark$ New Classics; According to this school, which is also known as rational expectations school, the crisis is caused by external shocks and is short-lived. Because of the rationality of individuals, the market will recover from the crisis by finding the balance after the shock.

$\checkmark$ According to the Neo-Keynesians, there are no mechanisms in the economic system to ensure balance. Therefore, state intervention is mandatory. The instability in aggregate demand will cause a crisis in the absence of state intervention. The decrease in demand will also cause the national income level to decrease.

$\checkmark$ Post-Keynesians explain the crisis by using Keynes' uncertainty approach and asymmetric information approach together. The most important name of the PostKeynesian school is Hyman Minsky. Minksy explains the crises with the "Financial Fragility Hypothesis".

According to Kindleberger; the crisis is the burst of the bubble formed in the markets and the road to the crisis begins with a sharp drop in asset prices. Therefore, the collapse begins when the market participants, who are in a panic mood as a result of speculation, sell their assets. With the collapse, firms bankrupt and foreign exchange markets fall. Kindleberger sees this situation as inevitable for the market system and states that in a rising economy, the conjuncture will surely enter a crisis after a certain point.

In this study, these statements of Kindleberger will be tested econometrically.

\section{Literature Review}

Financial bubbles attract much interest in the field of finance, both in theory and practice. However, it is seen that the studies on bubbles are mainly conducted on developed markets. At this point, overcoming a lack of literature to test the bubble effect on emerging markets is thought by this study. A small part of the studies on this subject is as follows;

Haque et al. (2008) investigated whether there is a financial bubble in the Chinese Stock Exchange with the duration dependency test developed by McQueen and Thorley. In the examination made on the Shanghai Index weekly closing values, a bubble was determined in the prices. The researchers, drawing attention to the importance of bubbles, emphasised that precautions should be taken in order not to encounter the problems experienced in the Asian Crisis again.

Fu and Bidarkota (2011) investigated the presence of bubbles in the S\&P 500 and Dow Jones indexes between 1949-2004. Bubbles in the relevant indices were found as a result of the study in which cointegration tests used. 
Kivedal (2012) examined whether there was a bubble in the housing prices in the USA during the 2007 Mortgage Crisis. In the study in which the relationship between rent and housing prices used, it was claimed that interest rates are also a significant factor in housing prices. The review period has started from 1960, and quarterly data were used. Empirical evidence for the presence of the bubble has obtained by using the VAR boundary test and autoregressive (ARCH) models.

Korkos (2014) analysed bubble presence in the S\&P 500 index using ADF, RADF, SADF and GSADF methods based on monthly data set of January 1990 - June 2014. According to empirical findings, dot.com bubble period has been determined. It was found that there was a bubble in the S\&P 500 in the 2008-2012 period.

Chang et al. (2014) investigated whether there is a bubble in the stock markets of BRICS countries in the 1990-2003-month period by using the test method developed by Phillips et al. In the study where SADF and GSADF tests used, multiple bubbles in BRICS were determined. The time series start date for each country varied due to difficulties in obtaining data. In the study where SADF and GSADF tests used, multiple bubbles in BRICS were determined. The time series start date for each country varied due to difficulties in obtaining data. The series starts in 1990M1 for Brazil, 1997M9 for Russia, 1990M7 for India, 1995M1 for China and 1995M6 for South Africa while the end date of all series is 2013M2. It was generally seen that the balloon period was the same as the Mortgage Crisis. Individually, the presence of bubbles was detected in the Brazilian market, especially in the 1992-1994 period, while in the Russian markets during 2005. In 1997-2000 dot-com bubble period, a bubble was also seen in India. In China, two bubbles were seen, and it was concluded that these bubble periods were 2007-2008.

In addition to these studies, the following studies can be given as examples: Flood and Garber (1980); Blanchard and Watson (1982); Edison, Luangaram and Miller (1998); Allen and Douglas (2000); Fukuta (2002); Boucher (2003); Gürkaynak (2008); Homm and Breitung (2010); Phillips, Shin and Yu (2011; 2013a; 2013b); Arshanapalli and Nelson (2013); Brunnermeier and Oehmke (2012); Caspi (2013); Chang (2014).

\section{Data Set and Methodology}

\section{Data Set}

In this study, bubble researches were conducted with Borsa İstanbul return indices and as macroeconomic variables, the indicators indicated by Kaminsky, Lizondo and Reinhart (1997) were used in the examination of the relationship between bubbles and financial crises. In this context, macroeconomic variables are considered as gross domestic product, foreign trade deficit, total external debt and real exchange rate (\$/€), budget deficit, credit/GDP, interest rates, domestic credit volume, M2 money supply and inflation. Right-tailed unit root tests were applied to the return indices to detect bubbles and the relationship between detected bubbles and macroeconomic variables was examined by asymmetric causality test which takes positive and negative shocks into account. 
The index selected for the bubble research at Borsa İstanbul is the BIST100 return index. In BIST Equity Indices, which are calculated as both price and return, the only difference between these two indices arises in cash dividend payments. In cash dividend payments; while the dividend value of the return index is corrected with the assumption that the dividend paid is invested in the shares included in the index in proportion to their weight; the dividend value of the price index is not adjusted with the assumption that the dividend paid is excluded from the portfolio (Borsa İstanbul, 2018). The calculation formula of the indices is as follows:

$$
E_{t}=\frac{\sum_{i=1}^{n}\left(\frac{F_{i t}}{D_{t}}\right) * N_{i t} * H_{i t} * K_{i t}}{B_{t}}
$$

Here the symbols refer to:

"Et; value of index at time $t, n$; number of shares (companies) included in the index, Fit; the price of the "i" share at time $t, \mathrm{Nit}$; Total number of " $i$ " shares at time $t$, Hit; The ratio of the " $i$ " share in the actual circulation used in the calculation of the index at time $t$ to the total number of shares, Kit; coefficient of “i” pay share at time t, Dt; Value of the index's exchange rate at time $\mathrm{t}, \mathrm{Bt}$; Divisor value of the index at time t" (Borsa Istanbul, 2018).

Since a financial asset such as a stock has not only a capital gain but also a dividend income; as well as the change in the price of such an asset, the return from that price is important in the search for bubbles. Because when examining the bubbles formed in asset prices; if the same rate of return can be obtained from the asset in return for the high price paid to the asset, the asset price is considered to be at the required price. If the asset price is higher than the return from that asset, it can be accepted that there is a bubble in the asset price.

\section{Method 1: GSADF Test}

Right-tailed unit root tests give more effective results in detecting asset price bubbles than other unit root tests. For this reason, the GSADF multiple bubble tests were used in the study. This test is based on the following regression in the context of the right-tailed unit root test- DF test developed by Phillips et al:

$$
\Delta p t=\alpha+(\beta-1) p_{t-1}+\varepsilon_{t}+\varepsilon_{t} \sim \operatorname{iid}\left(0, \sigma^{2}\right)
$$

The $\mathrm{H}_{0}$ hypothesis is the null hypothesis that says there is no unit root and bubbles. $\mathrm{H}_{1}$ is the alternative hypothesis which claims that there are an explosive process and bubble. In other words;

It is expressed as $\mathrm{H}_{1}=\beta>1$ (right tail) 
This right tail unit root SADF test whose hypothesis given is subject to criticism of the inability to detect bubbles when there are multiple explosive processes in a time series. GSADF test eliminates this deficiency of SADF test and can detect multiple explosive processes. The GSADF test is called a multiple bubble test and the test window is more flexible than the SDAF test. The main idea of the GSADF test is based on the recursive repetition of the ADF test in the sample range like the SADF test. However, the GSADF test is an extended version of the SADF test (Zeren and Y1lanc1, 2019, p. 87). Phillips et al. (2013) report that multiple explosive processes in the time series are much more difficult to detect than a single explosive process. This is due to the nonlinear structure in the multiple bubble series.

The GSADF test uses flexible window widths. Unlike the SADF test, the GSADF test expands both the start and endpoints of the time series, rather than fixing the start point on the first observation. Since the GSADF test covers more sub-samples of the data and has more window flexibility, it is designed to perform better than the SADF test in detecting explosive behaviours when multiple events occur in the data (Phillips, Shi and Yu, 2013, p. 4). The GSADF test is described as follows (Phillips et al., 2013):

$$
\operatorname{GSADF}\left(r_{0}\right)=\sup _{\substack{r_{2} \in\left[r_{0}, 1\right] \\ r_{1} \in\left[0, r_{2}-r_{0}\right]}}\left\{A D F_{r_{1}}^{r_{2}}\right\}
$$

In the GSADF test which is time-varying right-tailed unit root test, unlike Phillips, Wu and Yu's SADF test, a window size is selected using the double support window selection system and the ADF test is applied to a sample with a window frame that gradually moves to the last sample (Zeren and Yllanc1, 2019, p. 86).

\section{Method 2: Asymmetric Causality}

Hacker and Hatemi-J (2006) found that the standard Granger test yields deviant results when the error terms of time series are not normally distributed or have ARCH structure. Therefore, they recommend using bootstrap distribution instead of asymptotic distribution. Hatemi-J (2012) argues, on the other hand, that even if there is no direct relationship between the variables, there may be an asymmetric causality relationship between the components of these variables (Yarasir-Tulumce and Zeren, 2017, p. 304). Hatemi-J uses Wald's statistics to test causality. Hatemi-J causality analysis is based on the following random process (Yllanc1 and Bozoklu, 2014, p. 214):

$$
\begin{aligned}
& y_{1 t}=y_{1 t-1}+\varepsilon_{1 t}=y_{1,0}+\sum_{i=1}^{t} \varepsilon_{1 i} \\
& y_{2 t}=y_{2 t-1}+\varepsilon_{2 t}=y_{2,0}+\sum_{i=1}^{t} \varepsilon_{2 i}
\end{aligned}
$$

$Y_{1 \mathrm{t}}$ and $Y_{2 \mathrm{t}}$ are two integrated series and $Y_{1,0}$ and $Y_{2,0}$ represent the initial values of the series. While testing the relationship between the variables, the variables are divided into positive and negative components. The expression of this situation is as follows; 


$$
\begin{aligned}
& \varepsilon_{1 i}^{+}=\operatorname{maks}\left(\varepsilon_{1 i}, 0\right), \varepsilon_{1 i}^{-} \min \left(\varepsilon_{1 i}, 0\right) \\
& \varepsilon_{2 i}^{+}=\operatorname{maks}\left(\varepsilon_{2 i}, 0\right), \varepsilon_{2 i}^{-} \min \left(\varepsilon_{2 i}, 0\right)
\end{aligned}
$$

The equation is reconstructed with the positive and negative components of these two variables;

$$
\begin{aligned}
& y_{1 t}=y_{1 t-1}+\varepsilon_{1 t}=y_{1,0}+\sum_{i=1}^{t} \varepsilon_{1 i}^{+}+\sum_{i=1}^{t} \varepsilon_{1 i}^{-} \\
& y_{2 t}=y_{2 t-1}+\varepsilon_{2 t}=y_{2,0}+\sum_{i=1}^{t} \varepsilon_{2 i}^{+}+\sum_{i=1}^{t} \varepsilon_{2 i}^{-}
\end{aligned}
$$

The positive and negative shocks in each variable are expressed in the following cumulative equation (Yilanc1, 2014):

$$
y_{1 i}^{+}=\sum_{i=1}^{t} \varepsilon_{1 i}^{+}, y_{1 i}^{-}=\sum_{i=1}^{t} \varepsilon_{1 i}^{-},
$$

After this stage, assuming that $\mathrm{Y}_{\mathrm{t}}^{+}=\left(\mathrm{Y}_{1 \mathrm{t}}{ }^{+}, \mathrm{Y}_{2 \mathrm{t}}{ }^{+}\right)$to find the causality relationship between positive components p-delay VAR model is defined as follows:

$$
Y_{t}^{+}=\alpha+A_{1} Y_{t-1}^{+}+\cdots+A_{p} Y_{t-1}^{+}+u_{t}^{+}
$$

Here, $\mathrm{p}$ denotes the number of delays and $\mathrm{Yt}(2 \mathrm{x} 1)$ shows the variable vector and AR shows (2x2) dimensional $r$-order parameter matrix. The Wald statistics used for the test are obtained through the VAR model.

\section{Application}

GSADF test was used to detect bubbles due to the high level of efficacy. Critical values of the test were obtained by Monte Carlo Simulation. 
Table 1. GSADF Test Results

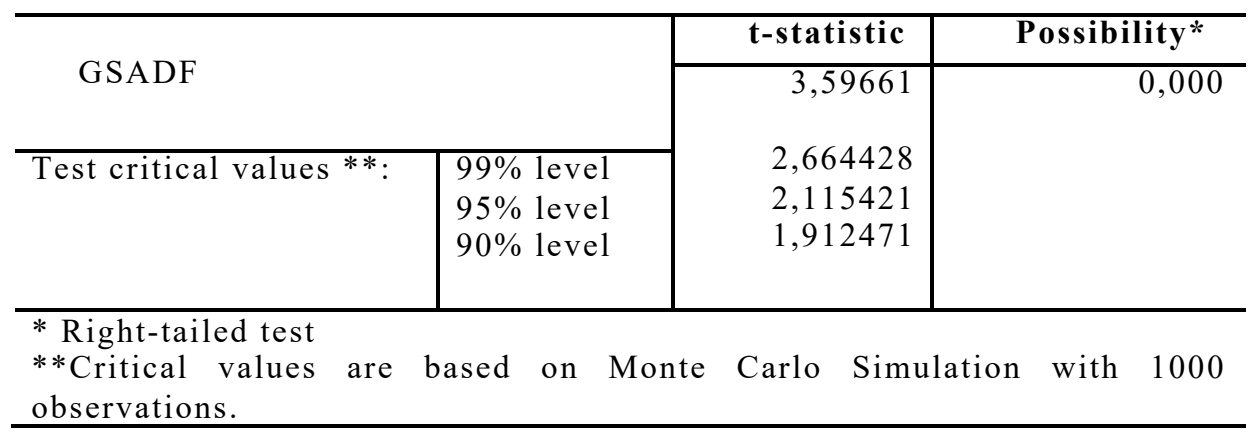

GSADF test t-statistic result in Table $1(3,59661)$ is greater than the test critical value calculated by Monte Carlo Simulation. The GSADF test null hypothesis $\mathrm{H}_{0}$ is rejected based on these results. The acceptance of the $\mathrm{H}_{1}$ alternative hypothesis, which indicates that there is a bubble, indicates the presence of an explosive process in the series. This is also expressed as $H_{1}=\beta>1$.

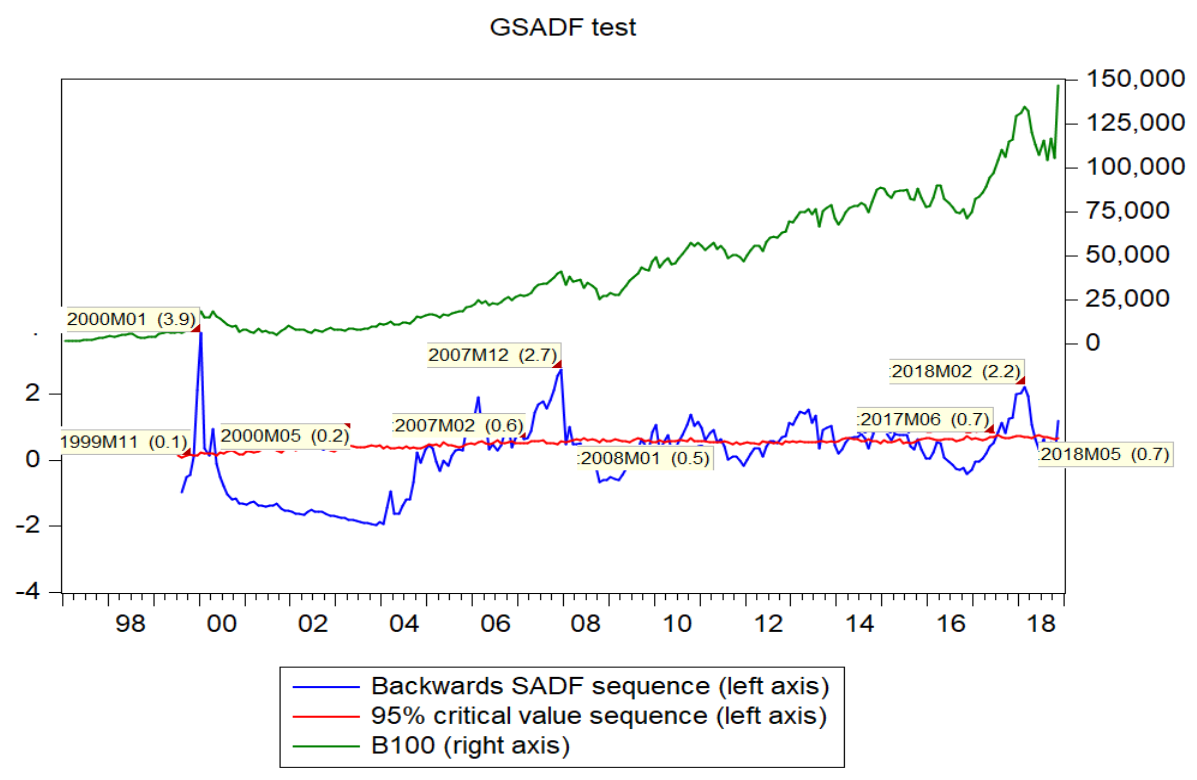

Figure 1. Bubble Periods

Bursts in the series and related periods are given in Figure 1. Three bubbles exceeding $20 \%{ }^{5}$ were found in the return series of the BIST 100 index. The first bubble is in 2000, the second bubble in 2007 and the third bubble in 2018. As can be seen in Figure 1, the periods of bubble burst coincide with a period before the financial crises.

In the Engle-Granger causality test, the variables are expected to be stationary at the same level. According to the unit root test results in Table 2, the variables used in this study are not stationary at the same level. Hence, Hatemi-J causality test, which does not have any restriction

${ }^{5}$ Mishkin and White (2002) describe the bubble as a fall in the asset market average of more than $20 \%$ in a given period. In addition, the IMF describes a $20 \%$ drop in asset prices in a given period as a bubble collapse. 
on the level of stasis between variables and also examines the positive and negative shocks of the variables on a causal basis, is preferred for the application.

Table 2. Unit Root Test Results

\begin{tabular}{|c|c|c|c|}
\hline Variables & Stability Level & t-statistic & Possibility \\
\hline \multirow[t]{2}{*}{ FD } & $\mathrm{I}(0)$ & -1.88548 & 0.3376 \\
\hline & $\mathrm{I}(1)$ & -7.328302 & $0.000 * * *$ \\
\hline \multirow[t]{2}{*}{ FTD } & I(0) & -1.99399 & 0.289 \\
\hline & $\mathrm{I}(1)$ & -8.42168 & $0.000 * * *$ \\
\hline \multirow[t]{2}{*}{ ER } & $\mathrm{I}(0)$ & -0.22754 & 0.9297 \\
\hline & & -6.36337 & $0.000 * * *$ \\
\hline INF & $\begin{array}{l}\mathrm{I}(0) \\
\mathrm{I}(1)\end{array}$ & $\begin{array}{l}-3.14001 \\
-3.97309\end{array}$ & $\begin{array}{r}0.0275 \\
0.0025 * * *\end{array}$ \\
\hline \multirow[t]{2}{*}{ IR } & $\mathrm{I}(0)$ & -1.79636 & 0.3799 \\
\hline & $\mathrm{I}(1)$ & -7.46549 & $0.000 * * *$ \\
\hline \multirow[t]{3}{*}{$\mathrm{GDP}^{1}$} & $\mathrm{I}(0)$ & -2.07228 & 0.2563 \\
\hline & $\mathrm{I}(1)$ & -1.71762 & 0.4186 \\
\hline & $\mathrm{I}(2)$ & -46.7799 & $0.0001^{* * *}$ \\
\hline \multirow[t]{3}{*}{$\mathrm{CV}$} & $\mathrm{I}(0)$ & -2.18779 & 0.2123 \\
\hline & $\mathrm{I}(1)$ & -3.14215 & 0.0274 \\
\hline & $\mathrm{I}(2)$ & -16.1577 & $0.0001 * * *$ \\
\hline \multirow[t]{3}{*}{ Credit/CDP } & $\mathrm{I}(0)$ & 0.651563 & 0.9903 \\
\hline & $\mathrm{I}(1)$ & -1.67141 & 0.4418 \\
\hline & $\mathrm{I}(2)$ & -8.97624 & $0.000 * * *$ \\
\hline \multirow{3}{*}{$\begin{array}{l}\mathrm{M} 2 \\
\mathrm{BD}\end{array}$} & $\mathrm{I}(0)$ & -5.35742 & $0.000 * * *$ \\
\hline & $\mathrm{I}(0)$ & -0.65094 & 0.8553 \\
\hline & $\mathrm{I}(\mathrm{I})$ & -14.862 & $0.000 * * *$ \\
\hline
\end{tabular}

According to the unit root results in Table 2, the M2 money supply variable is stationary, while the variables of external debt, foreign trade deficit, exchange rate, inflation and interest rate are stationary in the first degree. GDP, credit volume and credit / GDP variables are also stationary at Level 2.

Kindleberger describes the factors that cause bubble as the decrease in interest rate, increase in credit volume and money supply, and interpret the bubble burst as a deterioration in the main indicators while associating the bubble burst with the crisis. The main indicators obtained from the classification of Kaminsky, Lizondo and Reinhart are considered as result variables caused by the bubble in this study.

After the bubble burst phase is reached, the financial crisis is expected in an environment of panic sales, that is to say, the collapse phase. A dramatic increase in the budget deficit and inflation, a decrease in GDP and an increase in foreign debt and foreign trade deficit are expected in such a case. These alleged relationships were examined with the Hatemi-J Asymmetric causality test and the results of the test are given in Table 3.

\footnotetext{
${ }^{6}$ Seasonality was determined in the series. The seasonally adjusted series were used in the analysis.
} 


\section{Table 3. Asymmetric Causality Test Results}

\begin{tabular}{|c|c|c|c|c|}
\hline $\begin{array}{l}\text { Fundamental } \\
\text { Hypothesis }\end{array}$ & Wald & $1 \%$ & $5 \%$ & $10 \%$ \\
\hline $\mathrm{IR}^{-}---/--->\mathrm{B} 100^{+}$ & $10.493 * *$ & 11.876 & 8.67 & 7.073 \\
\hline $\mathrm{CV}^{+}---/--->\mathrm{B} 100^{+}$ & $43.499 * * *$ & 17.262 & 9.55 & 7.739 \\
\hline $\mathrm{M}^{+}----/-->>\mathrm{B} 100^{+}$ & $14.587 * *$ & 21.528 & 10.0 & 8.068 \\
\hline B100----/--->BD ${ }^{+}$ & $39.653 * * *$ & 15.016 & 10.377 & 8.269 \\
\hline B100----/--->FD ${ }^{+}$ & $9.981 * * *$ & 8.452 & 4.321 & 2.86 \\
\hline B100----/--->FTD ${ }^{+}$ & 2.134 & 8.582 & 4.454 & 2.871 \\
\hline B100----/---> $\mathrm{INF}^{+}$ & 0.044 & 8.78 & 4.4 & 2.966 \\
\hline B100----/--->GDP- & $10.6^{*}$ & 18.914 & 12.452 & 9.991 \\
\hline $\mathrm{B} 100^{-}---/--->\mathrm{C} / \mathrm{CDP}^{+}$ & 6.796 & 22.212 & 13.305 & 9.422 \\
\hline B100----/---> ER ${ }^{+}$ & $3.52 *$ & 9.372 & 4.494 & 2.908 \\
\hline
\end{tabular}

In Table 3, “+” means the mathematical positive component of the variables and “-” indicates the mathematical negative component.

The symbol of “---/--->" represents the null hypothesis that there is no causality. In the results related to the Borsa Istanbul indices where the bubble periods were determined; when the bubble process is examined, it is seen that the increase in credit volume in the environment of low-interest rates causes a positive increase in the bubble. According to Kindleberger who claims that the burst of bubbles will lead to financial crises, growth is adversely affected during the collapse phase.

It was observed that the factors that feed the bubble in the BIST100 index returns, as Kindleberger and Aliber (2015b) mentioned, are the decline in interest rates, high credit volume and increased the money supply. According to the statistical results obtained, the null hypothesis that there is no relationship between these variables was rejected. In other words, the assumption of incentives -which are the fall in interest rates, the expansion of loans, and the subsequent increase in asset prices - for economic development in the Minsky model was accepted as valid when the BIST100 return index was analysed.

\section{Conclusion}

In this study, which investigated financial bubbles in Borsa Istanbul, right-tailed unit root tests identified by Phillips et al. (2013) were performed based on Kindleberger's terminology, which examines market panic and claims that financial crises are related to the burst of bubbles in the market.

In the financial time series analysis, although the price series were stochastic and diverging from the average, return series were used in the study because they are distributed around the average and contain more information. Right-tailed unit root tests assume that, despite the swelling in asset prices, there are explosive processes in the series if returns do not increase at the same rate. According to these test results, three bubbles were found in Borsa Istanbul 100 return index in 1999-2000, 2007-2008, 2017-2018 periods. 
Hatemi-J Asymmetric Causality test was used to test the relationship between macroeconomic variables and financial bubbles. According to the results of Hatemi-J test, which makes causality tests by taking positive and negative shocks of variables into consideration, there is a relationship between bubbles and financial crises and the factors that cause the bubble in the BIST 100 index are the interest rate, credit volume and money supply. The factors caused by the bubble burst, on the other hand, decreased in the budget deficit, foreign debt and exchange rate and gross domestic product. Contrary to expectations, no relationship was found between credit / GDP variable in the collapse phase.

In these results, Kindleberger's claim -within the framework of Minksy's Financial Instability Hypothesis- that the bubbles cause financial crisis has been accepted statistically for Borsa Istanbul.

\section{References}

Allen, F. and Douglas G. (2000). Bubbles and crises, The Economic Journal, 11, 236-255, doi: 10.1111/1468-0297.00499.

Arshanapalli, B. and Nelson W. B. (2016). Testing for stock price bubbles: a review of econometric tools. The International Journal of Business and Finance Research, 10(4), 2942.

Barlevy, G. (2007). Economic theory and asset bubbles. Economic Perspective, 31(3), 44-59.

BİST (2018). Available at: https://www.borsaistanbul.com/en/home-page.

Blanchard, O. J., Watson, M. W. and Watchtel, P. (1982). Bubbles, rational expectations and financial markets, crises in the economic and financial structure. Watchtel P. (Ed). MA: LexingtonBooks.

Boucher, C. (2003). Testing for rational bubbles with time varying risk premium and nonlinear cointegration: evidence from the US and French stock markets, Research Paper, France: Universite Paris-Nord. Doi: 10.1.1.595.9068

Brunnermeier, M. K. and Oehmke, M. (2012). Bubbles, financial crises, and systemic risk. NBER Working Paper. 18398, 1221-1288. Doi: 10.3386/w18398.

Chang, T., Aye C.G. and Gupta R. (2014). Testing for multiple bubbles in the BRICS stock markets, University of Pretoria Department of Economics Working Paper Series No: 201407, 1-22.

Edison, H., Luangaram, P., Miller, M., (1998). Asset bubbles, domino effects and 'lifeboats': elements of the East Asian Crisis. Paper presented at the CEPR-World Bank Conference on Financial Crises: Contagion and Market Volatility, London. Doi: 10.1177/002795019816500109 
Flood, R. P. and Garber P. M. (1980). Market fundamentals versus price level bubbles: the first tests, Journal of Political Economy, 88, 745-770. Doi: 10.1086/260900

Fu, M. and Bidarkota P.V. (2011). Periodically collapsing bubbles in stock prices cointegrated with broad dividends and macroeconomic factors. Journal of Risk and Financial Management, 4, 97-132.

Fukuta, Y. (2002). A Test for rational bubbles in stock prices. Empirical Economics, 27, 587-600.

Gürkaynak, R. S. (2008). Econometric tests of asset price bubbles: taking stock. Journal of Economic Surveys, 22(1), 166-186. Doi: 10.1111/j.1467-6419.2007.00530.x

Hacker, R. S. and Hatemi-J, A. (2006). Tests for causality between integrated variables using asymptotic and bootstrap distributions: theory and application. Applied Economics, 38(13), 1489-1500, Doi: 10.1080/00036840500405763

Haque, A., Shaoping W. and Hongping O.(2008). Rational speculative bubbles in Chinese stock market. International Journal of Applied Economics, 5(1), 85-100.

Hatemi-J, A. (2012). Asymmetric causality tests with an application. Empirical Economy, 43(1), 447-456, Doi:10.1007/s00181-011-0484-x

Homm, U. and Breitung J. (2010). Testing for speculative bubbles in stock markets: a comparison of alternative methods. Journal of Financial Econometrics, 10(1), 198-231. Doi: 10.1093/jjfinec/nbr009

IMF. (2003, April). When bubbles burst?. Available at: https://www.imf.org/en/Publications/WEO/Issues/2016/12/31/Growth-and-Institutions

Kaminsky, G., Lizondo, S. and Reinhart, C.M. (1997). Leading indicators of currency crises. IMF Working Paper. 1-46.

Kindleberger, C. P. (1978a). Manias, panics, and crashes: a history of financial crises, New York: Wiley Investment Classics.

Kindleberger, C. P. (2000b). Manias, panics and crashers: a history of financial crisis. London: Macmillan.

Kindleberger, C. P. and Aliber, R.Z. (2011a). Manias, panics and crashes: a history of financial crises (6th Ed), New York: Palgrave Macmillan.

Kindleberger, C. P. and Aliber R. Z. (2015b). Manias, panics and crashes: a history of financial crises (7th Ed) New York:, Palgrave Macmillan.

Kivedal, B.K.(2012).Testing for rational bubbles in the housing market. Working Paper Series of Department of Economics Norwegian University of Science and Technology, 10, 1-17.

Komaromi, G. (2004). Anatomy of stock market bubbles. Hyderabad: The Institute of Chartered Financial Analysts of India (ICFAI) University. 
Korkos, I. (2014). Detecting bubbles in asset price: an empirical investigation in the US stock exchange market. Atina: School of Economics, Business Administration \& Legal Studies A Thesis Submitted For The Degree of Master Of Science (Msc) in Banking \& Finance. Available at: https://www.academia.edu/8603506/Detecting bubbles in asset prices an empirical investigation in the US stock exchange market

Phillips, P. C.B., Shi, S.-P. and Yu J. (2013) Testing for multiple bubbles 2: limit theory of real time detectors. Research Collection School of Economics, Singapore Management University. Available at: https://ink.library.smu.edu.sg/soe_research/1511

Stiglitz, J. (1990). Symposium on bubbles. The Journal of Economic Perspective, 4(2), 13-18.

Watanabe, K., Takayasu, H. ve Takayasu, M. (2007). A mathematical defination of the financial bubbles and crashes. Physica A, 383, 120-124.

Yaraşır-Tümlüce, S. and Zeren, F. (2017). Analysis of the relationshıp between public expenditures and economic growth in Turkey by asymmetric causality test. Int. Journal of Management Economics and Business, 13(2), 299-310.

Yılanc1, V. and Bozuklu, Ş. (2014). Price and trade volume relationship in Turkish stock market: a time-varying asymmetric causality analysis. Ege Academic Review, 14(2), 211-220.

Zeren, F. and Yllanc1, V. (2019). Are there multiple bubbles in the stock markets? further evidence from selected countries. Ekonomika, 98(1), 81-95. Doi: https://doi.org/10.15388/Ekon.2019.1.5 